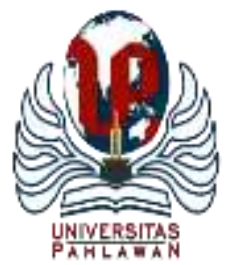

Edukatif : Jurnal Ilmu Pendidikan Volume 3 Nomor 6 Tahun 2021 Halm 4274 - 4288

EDUKATIF: JURNAL ILMU PENDIDIKAN

Research \& Learning in Education

https://edukatif.org/index.php/edukatif/index

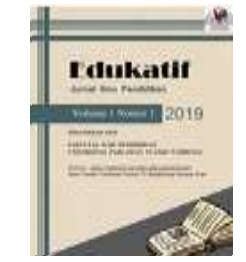

\title{
Pengembangan Bahan Ajar Membaca Sastra Berbasis Pendekatan Kontekstual pada Siswa SMP
}

\author{
Junifer Siregar \\ Universitas HKBP Nommensen Pematangsiantar, Indonesia \\ E-mail : junifersiregar08480@gmail.com
}

\begin{abstract}
Abstrak
Penelitian ini bertujuan untuk mendeskripsikan gambaran sikap siswa dan guru di SMP Negeri 1 Pematangsiantar, mengenai pembelajaran membaca sastra dan buku teks pelajaran bahasa Indonesia, mengetahui wujud kontekstual dari lingkungan sehari-hari siswa, RPP, dan buku teks pelajaran bahasa Indonesia, serta mengembangkan bahan ajar membaca sastra berbasis pendekatan kontekstual. Jenis penelitian ini merupakan Research and Development (R\&D). Hasil penelitian menghasilkan bahan ajar membaca sastra berbasis kontekstual pada siswa kelas VIII SMP, yang terdiri dari tiga bagian, bagian pertama berupa penyajian sampul luar, kata pengantar, penyajian SK dan KD, pendahuluan, daftar isi, dan tinjauan membaca sastra. Bagian kedua berupa isi yang didasarkan SK dan KD yaitu mengidentifikasi unsur intrinsik teks drama, membuat sinopsis novel remaja, menjelaskan alur cerita, pelaku, dan latar novel, dan mengenali ciri-ciri umum puisi dari buku antologi puisi, dan di akhir pembelajaran dicantumkan uji formatif dan evaluasi diri. Bagian ketiga dari penyajian buku ini terdiri dari glosarium, kunci jawaban, dan daftar pustaka.
\end{abstract}

Kata Kunci: pengembangan bahan ajar, membaca sastra, pendekatan kontekstual.

\section{Abstract}

This study aims to describe the attitudes of students and teachers at SMP Negeri 1 Pematangsiantar, regarding learning to read Indonesian literature and textbooks, knowing the contextual manifestations of the students' daily environment, lesson plans, and Indonesian language textbooks, as well as developing reading teaching materials. contextual approach-based literature. This type of research is Research and Development $(R \& D)$. The results of the study resulted in teaching materials for reading contextual literature to class VIII SMP students, which consisted of three parts, namely the presentation of the outer cover, the introduction, the presentation of $S K$ and $K D$, the introduction, the table of contents, and reading literature. The second part is based on SK and KD, namely identifying the intrinsic elements of drama texts, making a synopsis of youth novels, explaining the storyline, actors, and novel settings, and recognizing the general characteristics of poetry from poetry anthology books, and at the end of the lesson a formative test is included. and selfevaluation. The third part of the presentation of this book consists of a glossary, answer keys, and bibliography.

Keywords: development of teaching materials, reading literature, contextual approach.

Copyright (c) 2021 Junifer Siregar

$\square$ Corresponding author

Email : junifersiregar08480@gmail.com

DOI : https://doi.org/10.31004/edukatif.v3i6.1441 
4275 Pengembangan Bahan Ajar Membaca Sastra Berbasis Pendekatan Kontekstual pada Siswa SMP - Junifer Siregar

DOI: https://doi.org/10.31004/edukatif.v3i6.1441

\section{PENDAHULUAN}

Pada standar kompetensi (SK) membaca di SMP pada tiap tahunnya, di bagi dua SK tentang membaca di aspek sastra. Membaca itu misalnya membaca cerpen, novel, puisi, teks drama, dan sebagainya. Standar kompetensi tersebut diturunkan lagi menjadi kompetensi dasar (KD) yang masing-masing mempunyai tujuan pembelajaran masing-masing (Hamzah, 2019).

Untuk mencapai tujuan pembelajaran disetiap Kompetensi Dasarnya, guru harus mempersiapkan metode, strategi, dan media di samping buku paket atau bahan ajar sebagai acuannya (Siahaan et al., 2021). Ketika melihat kegiatan belajar sastra di beberapa kelas, sebagian besar guru hanya mengandalkan buku saja, misalnya buku paket, LKS, dan sebagainya. Dalam menyampaikan materi, guru hanya ceramah tanpa ada media yang dirancang. Sangat sedikit buku pelajaran atau bahan ajar lainnya yang memuat tentang keterampilan membaca khususnya di bidang sastra dengan suatu pendekatan tertentu (Pohan, 2020).

Masalah penting yang sering dihadapi guru dalam kegiatan pembelajaran adalah memilih atau menentukan materi pembelajaran atau bahan ajar yang tepat dalam rangka membantu siswa mencapai kompetensi Aisyah et al.,( 2020); Sadjati, (2012). Hal ini disebabkan oleh kenyataan bahwa dalam kurikulum atau silabus, materi bahan ajar hanya dituliskan secara garis besar dalam bentuk "materi pokok". Bahan ajar merupakan salah satu komponen sistem pembelajaran yang memegang peranan penting dalam membantu siswa mencapai standar kompetensi dan kompetensi dasar. Jenis materi pembelajaran perlu diidentifikasi atau ditentukan dengan tepat karena setiap jenis materi pembelajaran memerlukan strategi, media, dan cara mengevaluasi (Duludu, 2017). Dan apabila ketiganya tersebut dirasa kurang perlu ditambahkan pendekatan.

Pendekatan yang dinilai cocok dalam mengembangkan bahan ajar tersebut adalah adalah pendekatan kontekstual. Pendekatan kontekstual bisa digunakan dalam bidang dan mata pelajaran apapun. Atikah, (2017) menyatakan bahwa kesadaran perlunya pendekatan kontekstual dalam pembelajaran didasarkan adanya kenyataan bahwa sebagian besar siswa tidak mampu menghubungkan antara apa yang mereka pelajari dengan bagaimana pemanfaatannya dalam kehidupan nyata. Pembelajaran yang selama ini mereka terima hanyalah penonjolan tingkat hafalan dari sekian rentetan topik atau pokok bahasan, tetapi tidak diikuti dengan pemahaman atau pengertian yang mendalam, yang bisa diterapkan ketika mereka berhadapan dengan situasi baru dalam kehidupannya. Ananda, (2019) menambahkan, ada kecenderungan dewasa ini untuk kembali pada pemikiran bahwa anak akan belajar lebih baik jika lingkungan diciptakan alamiah.

Pendekatan kontekstual ini merupakan suatu konsep belajar dimana guru menghadirkan situasi dunia nyata kedalam kelas dan mendorong siswa membuat membuat hubungan antara pengetahuan yang dimilikinya dengan penerapannya dalam kehidupan mereka sebagai anggota keluarga dan masyarakat (Wahyuni, 2020). Tujuh komponen utama pembelajaran efektif adalah konstruktivisme, menemukan, bertanya, masyarakat belajar, pemodelan, refleksi, dan penilaian sebenarnya. Hasibuan, (2014);Hutagaol, (2013). Tujuan utama dari pengembangan buku ajar pada keterampilan membaca adalah berusaha meningkatkan minat baca siswa. Dengan memperhatikan tujuh komponen pada pendekatan kontekstual, siswa diharapkan gemar membaca teks apapun dan membuat kegiatan membaca itu merupakan kegiatan yangmenyenangkan dan mengasyikan. Selain itu, juga untuk mencapai kompetensi dasar yang ingin diraih dan meningkatkan hasil belajar siswa Pebriana, (2017);Pramita et al., (2016).

Oleh karena itu, dalam penelitian ini dikembangkan bahan ajar dengan pendekatan kontekstual. Diharapkan bahan ajar ini memberikan sumbangan pengetahuan untuk dunia pendidikan pada tingkat SMP kelas VIII. Dan dapat meningkatkan motivasi dan minat belajar siswa, serta terjadi peningkatan hasil belajar siswa. Di dalam standar isi ruang lingkup ini meliputi Standar Kompetensi (SK) dan Kompetensi Dasar (KD). Standar isi ini dikelompokkan ke dalam SK-KD untuk semester 1 dan 2. Jika dilihat secara keseluruhan dari segi jenis kompetensinya, porsi SK-KD membaca dan menulis lebih banyak.

Hal tersebut dijelaskan lagi dalam PP No 19 pasal 26 ayat 3 yang menyebutkan bahwa "Kompetensi 
lulusan untuk mata pelajaran bahasa menekankan pada kemampuan membaca dan menulis yang sesuai dengan jenjang pendidikan". Selanjutnya, pada Pasal 21 ayat 2 diatur pula bahwa "Perencanaan proses pembelajaran dilakukan dengan mengembangkan budaya membaca dan menulis". Oleh karena itu, pembelajaran membaca dan menulis harus mendapatkan perlakuan khusus dari para guru bahasa Indonesia Alpian, (n.d.); Simanjuntak et al., (2020).

Berikut data fakta yang menujukkan bahwa kemampuan membaca dan menulis belum berkembang secara maksimal. Hasil studi UNESCO melalui Program for International Student Assessment (PISA) pada tahun 2003 menunjukkan bahwa keterampilan membaca anak-anak di Indonesia usia 15 tahun ke atas, berada pada urutan ke-39 dari 41 negara yang diteliti. Dari jumlah yang diteliti tersebut tampak bahwa 37,6\% hanya bisa membaca tanpa bisa menangkap makna serta 24,8 hanya bisa mengambil satu kesimpulan pengetahuan (Anas \& PdI, 2014).

Analisis kemampuan membaca siswa Indonesia di dunia Internasional didasarkan atas beberapa permasalahan. Pertama, permasalahan mengenai perubahan kemampuan membaca siswa di tiap negara dari tahun ke tahun. Kedua permasalahan mengenai kemampuan siswa dalam memecahkan butir soal sastra pada level lemah. Ketiga, permasalahan mengenai kemampuan siswa Indonesia dalam memecahkan butir soal sastra pada level sedang. Keempat, permasalahan mengenai kemampuan siswa Indonesia dalam memecahkan butir soal nonsastra pada level sedang. Kelima, permasalahan mengenai kemampuan membaca siswa Indonesia dalam memecahkan butir soal sastra pada level tinggi. Keenam, permasalahan mengenai kemampuan siswa Indonesia dalam memecahkan butir soal non sastra pada level tinggi. Ketujuh, permasalahan mengenai kemampuan siswa Indonesia dalam memecahkan butir soal sastra pada level sempurna. Kedelapan, permasalahan mengenai kemampuan siswa Indonesia dalam memecahkan butir soal nonsastra pada level sempurna (Suryaman, 2015). Jika melihat dari data fakta di atas, dapat disimpulkan bahwa jika kemampuan dan kebiasaan membaca belum berkembang pada diri siswa, secara otomatis dapat dikatakan bahwa kemampuan dan kebiasaan menulis tidak akan berkembang baik pula. Perlu diadakannya perubahan dari dalam diri kita sendiri sebagai guru yakni membiasakan diri untuk membaca dan menulis dan menguasai beragam wacana yang digunakan untuk pembelajaran berbahasa dan bersastra (Tantri, 2017).

Walaupun pelajaran membaca dan menulis mendapat penekanan yang berlebih, namun pembelajaran bahasa Indonesia aspek mendengarkan dan berbicara dapat diabaikan. Hal itu dikarenakan kegiatan mendengarkan, berbicara, membaca, dan menulis itu digunakan dalam berkomunikasi, yaitu oleh seseorang dalam berhubungan dengan yang lainnya. Bahasa dalam berkomunikasi digunakan untuk bertukar pikiran, perasaan, pendapat, imajinasi, dan sebagainya sehingga terjadi kegiatan sambut-menyambut (Rahmawati, 2016).

Untuk mencapai tujuan pembelajaran yang efektif perlu digunakannya pendekatan dalam pembelajaran bahasa Indonesia. Tidak kurang dari enam pendekatan yang bisa digunakan, salah satunya adalah pendekatan kontekstual. Mengapa menggunakan pendekatan ini? Karena pendekatan ini berpusat pada siswa dan berangkat dari pemikiran bahwa cara belajar yang terbaik adalah melalui cara siswa membangun pengalaman baru berdasarkan pengalaman awal. Tujuh prinsip dasar dalam pendekatan kontekstual adalah berbasis masalah, berbasis konteks, berbasis perbedaan, berbasis individu, berbasiskelompok, dan berbasis pendekatan otentik (Suryaman, 2008). Dengan menggunakan ke tujuh prinsip dasar tersebut diharapkan mencapai tujuan pembelajaran dengan baik. Tujuan utama dari pengembangan buku ajar pada keterampilan membaca adalah berusaha meningkatkan minat baca sastra siswa. Dengan memperhatikan tujuh komponen pada pendekatan kontekstual, siswa diharapkan gemar membaca teks apapun dan membuat kegiatan membaca itu merupakan kegiatan yang menyenangkan dan mengasyikan SUSANTI, (2019); Panggabean \& Danis, (2020). Selain itu, penelitian ini juga bertujuan untuk mengetahui siswa dan guru di SMP Negeri 1 Pematangsiantar, tentang pembelajaran membaca sastra dan manfaat buku teks pelajaran bahasa Indonesia, untuk mengetahui wujud kontekstual dari lingkungan sehari-hari siswa, telaah RPP, dan buku teks pelajaran yang digunakan di SMP 
4277 Pengembangan Bahan Ajar Membaca Sastra Berbasis Pendekatan Kontekstual pada Siswa SMP - Junifer Siregar

DOI: https://doi.org/10.31004/edukatif.v3i6.1441

Negeri 1 Pematangsiantar, untuk mengetahui cara mengembangkan bahan ajar membaca sastra berbasis pendekatan kontekstual pada kelas VIII di SMP Negeri 1 Pematangsiantar

\section{METODE PENELITIAN}

Penelitian ini menggunakan metode penelitian dan pengembangan atau yang biasa disebut dengan Research and Development. Haryati, (2012) menyebutkan bahwa Research and Development adalah metode penelitian yang digunakan untuk menghasilkan produk tertentu, dan selanjutnya menguji keefektifan produk tersebut. Produk yang dikembangkan dalam penelitian ini adalah Pengembangan Bahan Ajar Membaca Sastra Berbasis Pendekatan Kontekstual Pada Siswa Kelas VIII Negeri 1 Pematangsiantar yang terdiri dari dari 7 kelas. Jumlah guru yang digunakan sebagai sampel untuk mendapatkan data sebanyak 10 guru, sedangkan siswa berjumlah 116 orang. Uji validasi bahan ajar membaca sastra dilakukan oleh Drs. Roanld Hasibuan, M.Pd sebagai dosen pendidikan bahasa Indonesia Universitas HKBP Nommensen, dan uji coba terbatas siswa sebanyak 16 orang.

Jenis data yang digunakan adalah deskripsi kuantitatif yang berasal dari lembar angket untuk siswa dan guru dan lembar evaluasi ahli materi, guru, dan siswa dan format penelaahan untuk RPP dan buku teks pelajaran bahasa Indonesia yang digunakan. Skala yang digunakan untuk deskripsi kuantitaif adalah skala Likert. Skala yang digunakan dimulai dari "1" hingga " 5 ". Lembar evaluasi ahli materi, guru, dan siswa menggunakan rentangan sangat baik, baik, cukup baik, kurang baik, dan sangat kurang baik. Untuk lembar angket siswa dan guru menggunakan skala sikap dengan rentangan sangat setuju, setuju, netral, tidak setuju, dan sangat tidak setuju. Penilaian sikap digunakan untuk mengukur sikap seseorang terhadap objek tertentu (positif, netral, dan negatif) (Kurniawan \& Astalini, 2019). Analisis data dengan menggunakan deskriptif kuantitatif dan reduksi data. Analisis data yang dilakukan adalah telaah RPP dan buku teks Pelajaran yang digunakan, lembar angket siswa dan guru, lembar validitas untuk uji ahli, guru, dan lembar evaluasi untuk siswa.

Adapun tahapan penelitian, yang digunakan sebagai berikut:

\section{Research and information (penelitian dan pengumpulan informasi)}

Pengukuran kebutuhan, studi literatur penelitian dalam skala kecil, dan pertimbangan-pertimbangan dari segi nilai.

\section{Planning (perencanaan)}

Menyusun rencana penelitian meliputi kemampuan-kemampuan yang diperlukan dalam pelaksanaan penilitian, rumusan masalah dan tujuan yang hendak dicapai dengan penelitian tersebut, desain atau langkahlangkah penelitian kemungkinan pengujian dalam lingkup tersebut.

Develop preliminary (pengembangan produk)

Pengembangan bahan pembelajaran, proses pembelajaran, dan instrument evaluasi.

\section{Preliminary form of product (uji produk pendahuluan)}

Uji coba di lapangan pada 1-3 sekolah dengan 6-12 subjek uji coba. Selama uji coba diadakan pengamatan, wawancara, dan pengedaran angket.

\section{Main product revision (revisi produk utama)}

Memperbaiki/menyempurnakan hasil uji coba.

Main field testing (uji produk utama)

Melakukan uji coba yang lebih luas pada 5 sampai dengan 15 sekolahdengan 30 sampai dengan 100 orang subjek uji coba.

\section{Operational product revision (revisi operasional produk)}

Menyempurnakan produk hasil uji lapangan. 
4278 Pengembangan Bahan Ajar Membaca Sastra Berbasis Pendekatan Kontekstual pada Siswa SMP - Junifer Siregar

DOI: https://doi.org/10.31004/edukatif.v3i6.1441

\section{Operational field testing (uji operasional produk)}

Dilaksanakan 10-30 sekolah dan melibatkan 40-200 subjek. Pengujian dilakukan melalui angket, wawancara, dan observasi serta analisis hasil.

\section{Final product revision (revisi produk akhir)}

Penyempurnaan didasarkan masukan dari uji pelaksanaan lapangan.

\section{Disseminaton and implementation (pemanfaatan dan penyebarluasan)}

Melaporkan hasilnya dalam pertemuan professional dalam jurnal, dan bekerja sama dengan penerbit untuk penerbitan

Dari ke sepuluh langkah-langkah yang ditawarkan oleh Borg dan Gall di atas, hanya tiga tahap yang digunakan untuk mengembangkan bahan ajar membaca sastra berbasis pendekatan kontekstual. Tiga tahapan tersebut meliputi:

- Penelitian dan pengumpulan Informasi,

- Perencanaan dan,

- Pengembangan produk.

- Berikut penjelasan di tiap pengembangannya

\section{Penelitian dan Pengumpulan Informasi}

Tahap pertama dalam pengembangan bahan ajar membaca sastra adalah penelitian dan pengumpulan informasi yang berfungsi untuk menganalis kebutuhan di lapangan. Kegiatan pertama berupa penelitian deskriptif, yakni penggalian terhadap dimensi-dimensi kontekstual di dalam buku pelajaran, di dalam pelaksanaan pembelajaran, serta konteks kehidupan sehari-hari.

Disain penelitian yang digunakan dalam studi awal ini berbentuk studi deskriptif-eksploratif. Studi pendahuluan diarahkan untuk mengumpulkan informasi kondisi awal tentang pembelajaran dan buku pelajaran bahasa Indonesia. Melalui disain ini akan diperoleh gambaran siswa dan guru mengenai pembelajaran dan manfaat buku teks pelajaran bahasa Indonesia dan kerangka kontekstual melalui aspek kehidupan sehari-hari (siswa, orang tua, dan lingkungan sekolah), telaah RPP, dan telaah buku pelajaran bahasa Indonesiayang digunakan.

\section{Perencanaan Pembuatan Bahan Ajar Membaca Sastra Berbasis Pendekatan Kontekstual}

Setelah mendapat masukan dari siswa dan guru serta kerangka kontekstual dari kehidupan sehari-hari (siswa, orang tua, dan lingkungan sekolah), telaah RPP, dan telaah buku pelajaran bahasa Indonesia yang digunakan, langkah selanjutnya adalah membuat desain buku.

Awal mendesain buku adalah memilih format buku yang sesuai. Pada tahap ini juga mengumpulkan referensi-referensi serta teks bacaan yang sesuai dengan kompetensi dasar yang digunakan dalam pembuatan buku.

\section{Pengembangan Bahan Ajar Membaca Sastra Berbasis PendekatanKontekstual}

Setelah semua referensi terkumpul, tahap selanjutnya adalah pembuatan buku. Pembuatan buku dimulai darijudul, petunjuk penggunaan, standar kompetensi dan kompetensi dasar, kata pengantar, materi dan teks bacaan,tahapan berdasarkan pendekatan kontekstual, glosarium, dan daftar pustaka.

Setelah pembuatan buku selesai, maka peneliti harus berkonsultasi kepada dosen pembimbing apakah buku sudah layak untuk diujikan. Setelah berkonsultasi, buku ini belum merupakan produk final karena masih harus diuji validasi oleh ahli materi, guru, dan siswa.

Setelah buku di validasi oleh ahli materi dan guru langkah selanjutnya adalah uji coba siswa terbatas. Uji coba siswa dilakukan untuk mendapatkan informasi dari siswa selaku pengguna terkait kualitas bahan ajar membaca sastra yang dikembangkan. Uji ini dilakukan secara terbatas yakni 16 siswa. Analisis data dengan 
4279 Pengembangan Bahan Ajar Membaca Sastra Berbasis Pendekatan Kontekstual pada Siswa SMP - Junifer Siregar

DOI: https://doi.org/10.31004/edukatif.v3i6.1441

menggunakan deskriptif kuantitatif dan reduksi data. Analisis data yang dilakukan adalah telaah RPP dan buku teks Pelajaran yang digunakan, lembar angket siswa dan guru, lembar validitas untuk uji ahli, guru, dan lembar evaluasi untuk siswa.

\section{HASIL DAN PEMBAHASAN PENELITIAN}

\section{Deskripsi Data Gambaran Siswa dan Guru Mengenai PembelajaranMembaca Sastra dan Manfaat Buku Teks Pelajaran Bahasa Indonesia}

Dalam upaya memperoleh informasi gambaran sikap siswa dan guru. Dilakukan studi awal yang dilakukan oleh 116 siswa dan 10 guru dari tiga sekolah yang menjadi sampel penelitian. Studi awal ini dilakukan untuk mengetahui gambaran siswa mengenai pengalaman awal membaca sastra danmanfaat buku teks pelajaran bahasa Indonesia, dan gambaran guru mengenaiperencanaan pembelajaran membaca sastra dan manfaat buku teks pelajaran bahasa Indonesia yang digunakan.

\section{Tabel 1 Deskripsi Data Sikap Siswa Mengenai Pengalaman Awal Membaca Sastra}

\begin{tabular}{|c|c|c|c|c|}
\hline No. & Deskripsi Penilaian & $\sum$ Skor & $\begin{array}{l}\text { Rata-Rata } \\
\text { Skor }\end{array}$ & \\
\hline 1. & Kesukaan membaca karya sastra. & 339 & 2,9 & 72,5 \\
\hline 2. & $\begin{array}{l}\text { Membaca cerpen lebih dari dua judul dalam satu } \\
\text { bulan. }\end{array}$ & 330 & 2,8 & 71,1 \\
\hline 3. & $\begin{array}{l}\text { Membaca cerpen dari buku pelajaran bahasa } \\
\text { Indonesia. }\end{array}$ & 353 & 3,04 & 76,07 \\
\hline 4. & Membaca cerpen dari referensi lain & 292 & 2,5 & 62,9 \\
\hline 5. & Kesukaan membaca novel. & 334 & 2,87 & 71,9 \\
\hline 6. & Membaca novel lebih dari satu judul dalam sebulan. & 260 & 2,24 & 56,03 \\
\hline 7. & Kesukaan membaca novel remaja Indonesia. & 321 & 2,77 & 69,2 \\
\hline 8. & Kesukaan membaca novel terjemahan. & 328 & 2,83 & 70,7 \\
\hline 9. & Koleksi novel lebih dari satu buku. & 299 & 2,58 & 64,4 \\
\hline 10. & $\begin{array}{l}\text { Membaca teks drama lebih dari dua judul dalam satu } \\
\text { tahun }\end{array}$ & 269 & 2,32 & 57,97 \\
\hline 11. & Pernah membaca puisi di depan umum. & 322 & 2,77 & 69,4 \\
\hline 12 & Mampu mengenali ciri-ciri umum puisi & 301 & 2,6 & 65 \\
\hline \multicolumn{3}{|c|}{ Rata-Rata } & 2,69 & 67,25 \\
\hline
\end{tabular}

Sumber: Data Primer

Berdasarkan tabel di atas, rata-rata skor dari keseluruhan aspek adalah 2, 69 atau 67,25\% dengan kategori "baik". Pada data di atas, aspek yang mempunyai skor tertinggi adalah membaca cerpen dari buku bahasa Indonesiasebesar 3,04 atau 76,07\%. Aspek yang memiliki skor terendah adalah: siswa membaca novel lebih dari satu judul dalam sebulansebesar 2,24 atau 56,03\% dengan kategori "cukup baik"

Tabel 2. Deskripsi DataSikap Siswa Mengenai Manfaat Buku Teks PelajaranBahasa Indonesia

\begin{tabular}{lllll}
\hline No. & \multicolumn{1}{c}{ Deskripsi Penilaian } & NSkor & \multicolumn{2}{c}{$\begin{array}{c}\text { Rata-Rata \% } \\
\text { Skor }\end{array}$} \\
\hline 1. & $\begin{array}{l}\text { menggunakan pilihan kata dan bahasa } \\
\text { mudah } \\
\text { dipahami siswa. }\end{array}$ & 357 & 3,08 & 76,94 \\
\hline 2. & menggunakan banyak referensi & 344 & 2,97 & 74,14 \\
\hline 3. & dapat digunakan untuk belajar mandiri. & 287 & 2,47 & 61,85 \\
\hline 4. & dapat digunakan untuk belajar kelompok. & 256 & 2,21 & 55,17 \\
\hline
\end{tabular}


4280 Pengembangan Bahan Ajar Membaca Sastra Berbasis Pendekatan Kontekstual pada Siswa SMP - Junifer Siregar

DOI: https://doi.org/10.31004/edukatif.v3i6.1441

\begin{tabular}{|c|c|c|c|c|}
\hline 5. & $\begin{array}{llll}\text { dapat digunakan } & \text { karena } & \text { keruntutan dan } \\
\text { kecakupan } \\
\text { materi. }\end{array}$ & 316 & 2,72 & 68,10 \\
\hline 6. & $\begin{array}{l}\text { membuat siswa terdorong untuk mengungkapkan } \\
\text { ide, pikiran, gagasan, perasaan, dan informasi } \\
\text { kepada } \\
\text { orang lain, baik secara lisan maupun tertulis. }\end{array}$ & 338 & 2,9 & 72,84 \\
\hline 7. & mendorong siswa untuk melakukan pengamatan. & 344 & 2,97 & 74,14 \\
\hline 8. & $\begin{array}{l}\text { mendorong siswa menemukan pengalaman atau } \\
\text { pengetahuan sendiri. }\end{array}$ & 265 & 2,28 & 57,11 \\
\hline 9. & $\begin{array}{l}\text { memfasilitasi siswa untuk mengembangkan } \\
\text { pengetahuan atau pengalaman. }\end{array}$ & 311 & 2,68 & 67,02 \\
\hline 10. & mendorong siswa untuk bertanya & 328 & 2,83 & 70,69 \\
\hline 11. & $\begin{array}{l}\text { dapat memberikan kesempatan kepada siswa } \\
\text { untuk } \\
\text { membaca berbagai karya sastra }\end{array}$ & 336 & 2,89 & 72,41 \\
\hline \multicolumn{3}{|c|}{ Rata-Rata } & 2,72 & 68,18 \\
\hline
\end{tabular}

Tabel di atas menunjuukan bahwa rata-rata keseluruhan aspek sebesar 2,72 atau 68,18\% berkategori "baik". Aspek yang memiliki skor tertinggi adalah buku pelajaran bahasa Indonesia menggunakan pilihan kata dan bahasa yang mudah dipahami siswa sebesar 3,08 atau 76,94\%. Skor terendah sebesar 2,21 atau 55,17 di dapat buku pelajaran bahasa Indonesia dapat digunakan untuk belajar kelompok $(75,4 \%)$.

Tabel 3. Deskripsi Data Sikap Guru Mengenai Perencanaan Pembelajaran Membaca Sastra

\begin{tabular}{|c|c|c|c|c|}
\hline No. & Deskripsi Penilaian & $\sum_{\text {Skor }}$ & $\begin{array}{l}\text { Rata-Rata } \\
\text { Skor }\end{array}$ & $\%$ \\
\hline 1. & $\begin{array}{c}\text { Tujuan pembelajaran dirumuskan secara } \\
\text { sederhana, komunikatif, dan mendorong motivasi } \\
\text { siswa. }\end{array}$ & 36 & 3,6 & 90 \\
\hline 2. & $\begin{array}{l}\text { Penyusunan tujuan pembelajaran diddasarkan } \\
\text { padaindikator dari suatu kompetensi dasar. }\end{array}$ & 35 & 3,5 & 87,5 \\
\hline 3. & $\begin{array}{l}\text { Memberitahukan tujuan pembelajaran kepada } \\
\text { siswa, setiap mempelajari kompetensi baru. }\end{array}$ & 32 & 3,2 & 80 \\
\hline 4. & $\begin{array}{l}\text { Mengkondisikan siswa dan mengecek kesiapan } \\
\text { siswa sebelum pelajaran dimulai. }\end{array}$ & 35 & 3,5 & 87,5 \\
\hline 5. & $\begin{array}{l}\text { Materi dikembangkan sesuai dengan tujuan } \\
\text { pembelajaran. }\end{array}$ & 33 & 3,3 & 82,5 \\
\hline 6. & Materi dikembangkan atas dasar tema tertentu. & 29 & 2,9 & 72,5 \\
\hline 7. & $\begin{array}{l}\text { Materi dikembangkan dengan pertimbangan dari } \\
\text { aspek pembelajaran kontekstual. }\end{array}$ & 23 & 2,3 & 57,5 \\
\hline 8. & $\begin{array}{c}\text { Sumber dari materi yang dikembangkan } \\
\text { bervariasi (tidak hanya dari buku, majalah, internet, } \\
\text { dansebagainya) }\end{array}$ & 35 & 3,5 & 87,5 \\
\hline 9. & Guru sebagai fasilitator. & 32 & 3,2 & 85 \\
\hline 10. & Menggunakan media pembelajaran. & 29 & 2,9 & 72,5 \\
\hline 11. & $\begin{array}{l}\text { Menggunakan media pembelajaran yang } \\
\text { disesuaikan dengan tujuan pembelajaran. }\end{array}$ & 33 & 3,3 & 82,5 \\
\hline 12. & $\begin{array}{l}\text { Media pembelajaran didasarkan atas aspek } \\
\text { dalam pembelajaran kontekstual. }\end{array}$ & 29 & 2,9 & 72,5 \\
\hline 13. & Media pembelajaran dapat dimengerti siswa. & 34 & 3,4 & 80 \\
\hline
\end{tabular}


4281 Pengembangan Bahan Ajar Membaca Sastra Berbasis Pendekatan Kontekstual pada Siswa SMP - Junifer Siregar

DOI: https://doi.org/10.31004/edukatif.v3i6.1441

\begin{tabular}{|r|c|c|c|c|}
\hline 14. & Menggunakan strategi dan metode pembelajaran. & 32 & 3,2 & 80 \\
\hline 15. & $\begin{array}{c}\text { Strategi dan metode di alam skenario } \\
\text { pembelajaran sesuai dengan tujuan pembelajaran. }\end{array}$ & 32 & 3,2 & 80 \\
\hline 16. & $\begin{array}{c}\text { Strategi dan metode dalam skenario } \\
\text { pembelajaran disesuaikan dengan aspek-aspek di } \\
\text { dalam pembelajarankontekstual. }\end{array}$ & 26 & 2,6 & 65 \\
\hline 17. & $\begin{array}{c}\text { Strategi di dalam skenario pembelajaran sesuai } \\
\text { dengan karakteristik siswa. }\end{array}$ & 33 & 3,3 & 82,5 \\
\hline 18. & $\begin{array}{c}\text { Demi tercapainya tujuan pembelajaran, digunakan } \\
\text { model (guru maupun siswa) }\end{array}$ & 35 & 3,5 & 87,5 \\
\hline 19. & $\begin{array}{c}\text { Diberikan umpan balik kepada siswa setelah } \\
\text { pembelajaran. }\end{array}$ & 36 & 3,6 & 90 \\
\hline 20 & Teknik penilaian bervariasi sesuai kompetensi \\
yang ingin dicapai. & 34 & 3,4 & 85 \\
\hline & Rata-Rata & $\mathbf{3 , 2}$ & $\mathbf{8 0}$ \\
\hline
\end{tabular}

Sumber: Data Primer

Rata-rata skor berdasarkan tabel di atas sebesar 3,2 atau 80\% dengan kategori "baik". Skor tertinggi berdasarkan tabel di atas 3,6 atau 90\% dengan aspek tujuan pembelajaran dirumuskan secara sederhana, komunikatif, dan mendorong motivasi siswa, dan diberikan umpan balik kepada siswa setelah pembelajaran. Skor terendah diperoleh aspek materi dikembangkan dengan pertimbangan dari aspek pembelajaran kontekstual sebesar 2,3 atau 57,5\%.

Tabel 4. Deskripsi Data Sikap Guru Mengenai Manfaat Buku Teks Pelajaran Bahasa Indonesia

\begin{tabular}{rlccc}
\hline No. & \multicolumn{1}{c}{ Deskripsi Penilaian } & $\sum$ Skor & \multicolumn{1}{c}{$\begin{array}{c}\text { Rata-Rata } \\
\text { Skor }\end{array}$} & \% \\
\hline 1 & $\begin{array}{l}\text { Menggunakan pilihan kata dan bahasa yang mudah } \\
\text { dipahami } \\
\text { siswa. }\end{array}$ & 35 & 3,5 & 87,5 \\
\hline 2 & Digunakan guru sebagai salah satu bahan ajar. & 33 & 3,3 & 82,5 \\
\hline 3 & Digunakan siswa untuk belajar mandiri. & 35 & 3,5 & 87,5 \\
\hline 4 & Digunakan siswa untuk belajar kelompok. & 35 & 3,5 & 87,5 \\
\hline 5 & Digunakan siswa karena keruntutan dan kecakupan materi. & 34 & 3,4 & 85 \\
\hline 6 & $\begin{array}{l}\text { Membuat siswa teringat dengan pengalaman atau } \\
\text { pengetahuan sebelumna. }\end{array}$ & 34 & 3,4 & 85 \\
\hline 7 & $\begin{array}{l}\text { Membuat siswa terdorong untuk mengungkapkan ide, } \\
\text { pikiran, gagasan, perasaan dan informasi kepada orang lain, } \\
\text { baik secaralisan maupun tertulis. }\end{array}$ & 32 & 3,2 & 80 \\
\hline 8. & Membuat siswa terdorong untuk melakukan pengamatan. & 32 & 3,2 & 80 \\
\hline 9 & $\begin{array}{l}\text { Membuat siswa terdorong menemukan pengalaman } \\
\text { atau pengetahuan sendiri. }\end{array}$ & 26 & 2,6 & 65 \\
\hline 10 & $\begin{array}{l}\text { Memfasilitasi siswa mengembangkan pengetahuan atau } \\
\text { pengalaman }\end{array}$ & 19 & 1,9 & 47,5 \\
\hline 11 & Mendorong siswa untuk bertanya. & 31 & 3,1 & 77,5 \\
\hline 12 & Memberikan contoh kepada siswa untuk ditiru. & 22 & 2,2 & 55 \\
\hline 13 & Dapat digunakan untuk latihan siswa. & 34 & 3,4 & 85 \\
\hline 14 & $\begin{array}{l}\text { Dapat memberikan kesempatan kepada siswa untuk } \\
\text { Mengembangkan pengetahuan berbagai jenis membaca } \\
\text { khususnya membaca sastra. }\end{array}$ & & 3,5 & 87,5 \\
\hline 15 & $\begin{array}{l}\text { Dapat memberikan kesempatan kepada siswa untuk } \\
\text { membaca berbagai karya sastra. }\end{array}$ & 35 & 3,5 & 87,5 \\
\hline
\end{tabular}




\begin{tabular}{rrr}
\hline Rata-Rata & $\mathbf{3 , 1 5}$ & $\mathbf{7 8 , 7 5}$ \\
\hline
\end{tabular}

Sumber: Data Primer

Berdasarkan data pada tabel di atas, rata-rata skor diperoleh 3,15 atau 78,75\% dengan kategori "baik". Lima aspek memiliki yang memiliki skor tertinggi 3,5 atau $87,5 \%$ adalah buku bahasa Indonesia menggunakan pilihan kata dan bahasa yang mudah dipahami siswa, digunakan siswa untuk belajar mandiri, digunakan siswa untuk belajar kelompok dapat memberikan kesempatan kepada siswa untuk mengembangkan pengetahuan berbagai jenis membaca khususnya membaca sastra, dapat memberikan kesempatan kepada siswa untuk membaca berbagai karya sastra. Sedangkan skor terendah sebesar 1,9 atau 47,5\% pada aspek buku pelajaran bahasa Indonesia memfasilitasi siswa mengembangkan pengetahuan atau pengalaman.

\section{Wujud Kontekstual dari Lingkungan Sehari-Hari Siswa, RPP yang Disusun Guru, dan Buku Teks Pelajaran Bahasa Indonesia yang Digunakan}

Hasil penggalian informasi berkenaan dengan konteks kehidupan sehari- hari siswa berkenaan dengan lingkungan siswa, diperoleh gambaran bahwa wujud kontekstual pada strategi konstruktif berupa penyediaan sarana; pada strategi inkuiri berupa pemunculan masalah; pada strategi masyarakat belajar berupa pemecahan masalah melalui kerja kelompok; serta pada strategi refleksi berupa penciptaan rasa senang dan dukungan terhadap cita-cita.

Tabel 5. Wujud Kontekstual dalam Lingkungan Siswa

\begin{tabular}{|c|c|c|c|c|c|c|c|c|}
\hline \multirow[t]{2}{*}{ No. } & \multirow{2}{*}{$\begin{array}{c}\text { Aspek } \\
\text { Lingkungan } \\
\text { Siswa }\end{array}$} & \multicolumn{7}{|c|}{ Wujud Kontekstual } \\
\hline & & $\mathbf{K}$ & I & B & MB & $\mathbf{P}$ & $\mathbf{R}$ & PO \\
\hline 1. & $\begin{array}{c}\text { Kelompok } \\
\text { belajar }\end{array}$ & - & $\begin{array}{c}\text { Pemunculan } \\
\text { Maslah }\end{array}$ & - & $\begin{array}{c}\text { Pemecahan } \\
\text { Masalah via } \\
\text { kelompok }\end{array}$ & - & - & - \\
\hline 2. & $\begin{array}{l}\text { Rasa senang } \\
\text { bersekolah }\end{array}$ & - & - & - & - & - & $\begin{array}{c}\text { Penciptaan } \\
\text { Rasa } \\
\text { senang }\end{array}$ & - \\
\hline 3. & $\begin{array}{c}\text { Dukungan } \\
\text { orang tua, guru, } \\
\text { dan buku } \\
\text { pelajaran } \\
\text { bahasa } \\
\text { Indonesia } \\
\text { terhadap ita- } \\
\text { cita }\end{array}$ & - & - & - & - & - & $\begin{array}{l}\text { Dukungan } \\
\text { atas cita- } \\
\text { cita }\end{array}$ & \\
\hline \multirow[t]{2}{*}{4.} & $\begin{array}{l}\text { Perpustakaan } \\
\text { Sekolah }\end{array}$ & $\begin{array}{r}\text { Penye } \\
\text { diaan } \\
\text { sarana } \\
\end{array}$ & - & - & - & - & - & - \\
\hline & Mading & $\begin{array}{l}\text { Penye } \\
\text { diaan } \\
\text { sarana }\end{array}$ & & & & & & \\
\hline
\end{tabular}

Keterangan: $\mathrm{K}=$ konstruktif, $\mathrm{I}=$ Inkuiri, $\mathrm{B}=$ bertanya, $\mathrm{MB}=$ masyarakat belajar, $\mathrm{P}=$ pemodelan, $\mathrm{R}=$ refleksi, $\mathrm{PO}=$ penilain otentik, $-=$ tidak ditemukan 
Tabel 6. Wujud Kontekstual dari Orang Tua Siswa

\begin{tabular}{|c|c|c|c|c|c|c|c|c|}
\hline \multirow[t]{2}{*}{ No. } & \multirow{2}{*}{$\begin{array}{c}\text { Aspek } \\
\text { Lingkungan } \\
\text { Siswa }\end{array}$} & \multicolumn{7}{|c|}{ Wujud Kontekstual } \\
\hline & & $\mathbf{K}$ & I & B & MB & $\mathbf{P}$ & $\mathbf{R}$ & $\mathbf{P O}$ \\
\hline 1. & $\begin{array}{l}\text { Penyediaan } \\
\text { Perpustakaan } \\
\text { Rumah }\end{array}$ & $\begin{array}{c}\text { Penyediaan } \\
\text { Sarana }\end{array}$ & - & - & - & - & - & - \\
\hline 2. & $\begin{array}{l}\text { Cita-cita orang } \\
\text { tua atas anak }\end{array}$ & - & - & - & - & - & $\begin{array}{c}\text { Penciptaan } \\
\text { Dorongan }\end{array}$ & - \\
\hline 3. & $\begin{array}{l}\text { Keterlibatan } \\
\text { Orang tua } \\
\text { Dalam belajar } \\
\text { anak }\end{array}$ & - & - & - & - & - & $\begin{array}{c}\text { Penciptaan } \\
\text { Dorongan }\end{array}$ & - \\
\hline 4. & $\begin{array}{c}\text { Bentuk } \\
\text { keterlibatan } \\
\text { orang tua dalam } \\
\text { belajar } \\
\text { anak }\end{array}$ & - & - & - & - & - & $\begin{array}{c}\text { Penciptaan } \\
\text { Dorongan }\end{array}$ & - \\
\hline 5. & $\begin{array}{c}\text { Harapan orang } \\
\text { tua terhadap } \\
\text { putra/putri } \\
\text { yang di } \\
\text { sekolahkan }\end{array}$ & - & - & - & - & - & $\begin{array}{c}\text { Penciptaan } \\
\text { dorongan }\end{array}$ & - \\
\hline
\end{tabular}

Keterangan: $\mathrm{K}=$ konstruktif, $\mathrm{I}=$ Inkuiri, $\mathrm{B}=$ bertanya, $\mathrm{MB}=$ masyarakat belajar, $\mathrm{P}=$ pemodelan, $\mathrm{R}=$ refleksi, $\mathrm{PO}=$ penilain otentik. - = tidak ditemukan

Penyediaan sarana contohnya penyediaan perpustakaan di rumah. Contoh dari cita-cita orang tua terhadap anak yakni maju, pandai, sukses, berbakti kepada orang tua, mandiri, soleh, tekun dan teladan, menjadi dokter, polisi, tentara, pegawai pemerintahan, guru, menjadi orang yang berguna bagi nusa dan bangsa. Penciptaan dorongan berupa bentuk keterlibatan orang tua atas belajar anak contohnya menyuruh belajar tepat waktu, memantau belajar, dan tidak menyalakan televisi pada saat anak belajar. Contoh daripenciptaan dorongan berupa harapan orang tua atas anak yang disekolahkan meliputi pandai, sukses, mandiri, berguna, berbakti kepada orang tua, mengejar cita-cita, menjadi orang yang berkualitas, dan berakhlak mulia.

Tabel 7. Wujud Kontekstual dari Telaah RPP

\begin{tabular}{|c|c|c|c|c|c|c|c|c|}
\hline \multirow[t]{2}{*}{ No. } & \multirow{2}{*}{$\begin{array}{c}\text { Aspek } \\
\text { Lingkungan } \\
\text { Siswa }\end{array}$} & \multicolumn{7}{|c|}{ Wujud Kontekstual } \\
\hline & & $\mathbf{K}$ & I & B & MB & $\mathbf{P}$ & $\mathbf{R}$ & PO \\
\hline 1. & $\begin{array}{l}\text { Perumusan } \\
\text { tujuan }\end{array}$ & $\begin{array}{c}\text { Kata kerja } \\
\text { operasional }\end{array}$ & - & - & $\begin{array}{c}\text { Kegiatan } \\
\text { berkelom } \\
\text { pok/diskusi }\end{array}$ & - & - & - \\
\hline 2. & $\begin{array}{l}\text { Penyusunan } \\
\text { materi pokok } \\
\text { dan uraiannya }\end{array}$ & & $\begin{array}{c}\text { Pemecahan } \\
\text { masalah }\end{array}$ & - & - & - & & - \\
\hline
\end{tabular}


4284 Pengembangan Bahan Ajar Membaca Sastra Berbasis Pendekatan Kontekstual pada Siswa SMP - Junifer Siregar

DOI: https://doi.org/10.31004/edukatif.v3i6.1441

\begin{tabular}{|c|c|c|c|c|c|c|c|c|}
\hline 3. & $\begin{array}{l}\text { Pemilihan } \\
\text { bahan, alat, } \\
\text { dan media }\end{array}$ & $\begin{array}{l}\text { Penggunaan } \\
\text { media } \\
\text { pemicu }\end{array}$ & - & - & - & - & - & - \\
\hline 4. & $\begin{array}{l}\text { Pengembangan } \\
\text { skenario } \\
\text { pembelajaran }\end{array}$ & - & Pembuktian & $\begin{array}{l}\text { Ta nya } \\
\text { jawab }\end{array}$ & $\begin{array}{c}\text { Pemecahan } \\
\text { masalah } \\
\text { melalui } \\
\text { kelompok }\end{array}$ & - & Perenungan & $\begin{array}{l}\text { Unjuk } \\
\text { kerja }\end{array}$ \\
\hline
\end{tabular}

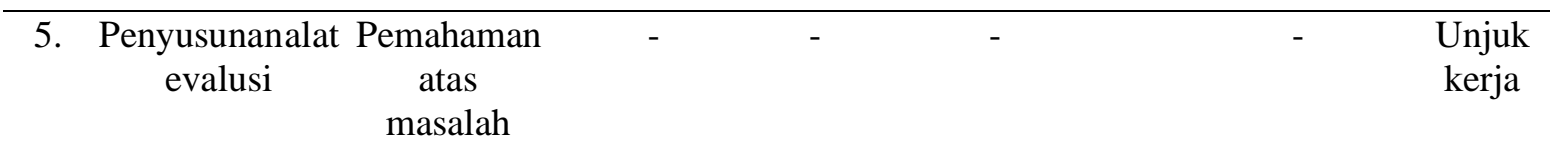

Keterangan: $\mathrm{K}=$ konstruktif, $\mathrm{I}=$ Inkuiri, $\mathrm{B}=$ bertanya, $\mathrm{MB}=$ masyarakat belajar, $\mathrm{P}=$ pemodelan, $\mathrm{R}=$ refleksi, $\mathrm{PO}=$ penilain otentik. $-=$ tidak ditemukan

Berdasarkan data pada tabel di atas, terdapat 9 wujud kontekstual dari aspek RPP yang disusun guru. Wujud kontekstual dari strategi konstruktif berupa, penggunaan kata kerja operasioanl, penggunaan media pemicu, dan pemahaman atas masalah. Wujud kontekstual dari strategi inkuiri diperoleh pemecahan masalah dan pembuktian. Wujud kontekstual dari strategi bertanya diperoleh berupa tanya jawab. Wujud kontekstual dari strategi masyarakat belajar berupa pemecahan masalah melalui kelompok. Wujud kontekstual dari penilaian otentik berupa unjuk kerja.

Tabel 8. Wujud Kontekstual pada Buku Pelajaran Bahasa Indonesia

\begin{tabular}{|c|c|c|c|c|c|c|c|c|}
\hline \multirow{2}{*}{$\begin{array}{l}\text { No } \\
\text { - }\end{array}$} & \multirow{2}{*}{$\begin{array}{c}\text { Aspek } \\
\text { Lingkungan } \\
\text { Siswa }\end{array}$} & \multicolumn{7}{|c|}{ Wujud Kontekstual } \\
\hline & & $\mathbf{K}$ & I & B & MB & $\mathbf{P}$ & $\mathbf{R}$ & PO \\
\hline 1. & Pendahuluan & $\begin{array}{c}\text { Pemetaan } \\
\text { masalah, } \\
\text { pengaitan } \\
\text { pengalaman, } \\
\text { pemicu }\end{array}$ & - & Apersepsi & - & - & - & - \\
\hline 2. & Materi & $\begin{array}{c}\text { Objek } \\
\text { pengamatan } \\
\text { dan } \\
\text { interpretasin } \\
\text { ya, pengaitan } \\
\text { pengalaman }\end{array}$ & - & - & $\begin{array}{c}\text { Pembentukan } \\
\text { etika }\end{array}$ & $\begin{array}{l}\text { Pemberi } \\
\text { an } \\
\text { contoh } \\
\text { Kebe } \\
\text { ragaman } \\
\text { contoh }\end{array}$ & $\begin{array}{c}\text { Keber } \\
\text { mak } \\
\text { naan }\end{array}$ & - \\
\hline 3. & $\begin{array}{c}\text { Penyajian } \\
\text { Materi }\end{array}$ & - & $\begin{array}{c}\text { Perlua } \\
\text { san } \\
\text { inform } \\
\text { asi, } \\
\text { peme } \\
\text { cahan } \\
\text { masala } \\
\text { h }\end{array}$ & $\begin{array}{c}\text { Doron } \\
\text { gan } \\
\text { melalui } \\
\text { pertanya } \\
\text { an, } \\
\text { bertanya } \\
\text { pada nara } \\
\text { sumber }\end{array}$ & - & - & & Berkarya \\
\hline
\end{tabular}




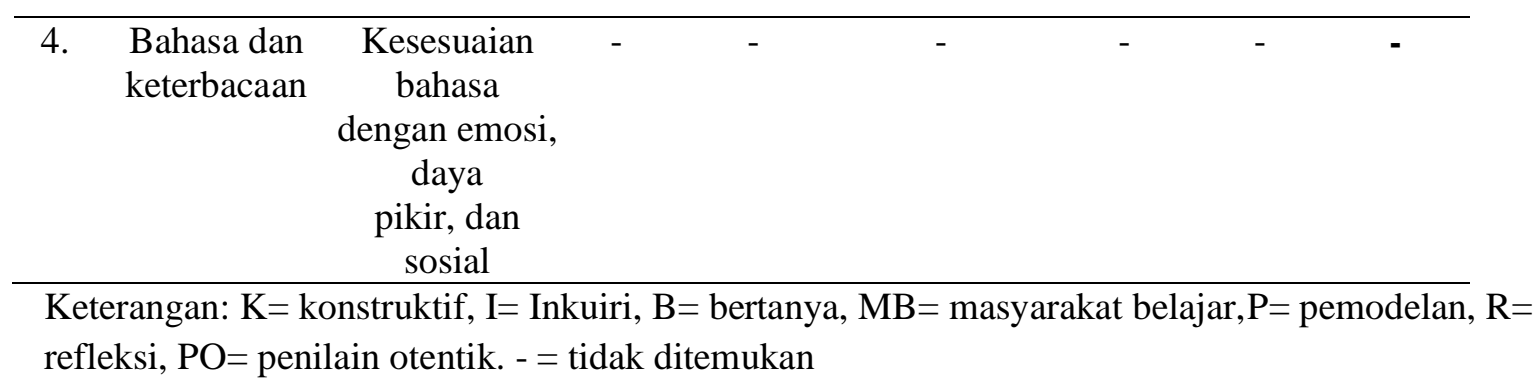

\section{Pengembangan Bahan Ajar Membaca Sastra Berbasis PendekatanKontekstual pada Siswa Kelas VIII SMP Negeri 1 Pematangsiantar}

Data hasil validasi guru 1 dan 2 dapat dilihat pada tabel berikut:

Tabel 9. Rata-Rata Skor Hasil Validasi Produk dari Guru Bahasa Indonesia 1

No. Aspek Penilaian Rata-RataSkor Kategori

\begin{tabular}{cccc}
\hline 1 & Kelayakan isi & 4,2 & Baik \\
\hline 2 & Bahasa dan gambar & 4 & Baik \\
\hline 3 & Penyajian & 4,05 & Baik \\
\hline 4 & Kegrafikaan & 4,5 & Sangat Baik \\
\hline & Jumlah & $\mathbf{1 6 , 7 5}$ & \\
\hline & Rata-Rata Skor & $\mathbf{4 , 2}$ & Baik \\
\hline
\end{tabular}

Tabel 10. Rata-Rata Skor Hasil Validasi Produk dari Guru BahasaIndonesia 2

\begin{tabular}{cccc}
\hline No. & Aspek Penilaian & Rata-RataSkor & Kategori \\
\hline 1 & Kelayakan isi & 4,3 & Sangat Baik \\
\hline 2 & Bahasa dan gambar & 4,6 & Sangat Baik \\
\hline 3 & Penyajian & 4,5 & Sangat Baik \\
\hline 4 & Kegrafikaan & 4,3 & Sangat Baik \\
\hline & Jumlah & $\mathbf{1 7 , 7}$ & \\
\hline & Rata-Rata Skor & $\mathbf{4 , 5}$ & Sangat Baik \\
\hline
\end{tabular}

Berdasarkan tabel di atas, skor yang diperoleh guru 1 dengan guru 2 ada sedikit perbedaan. Pada aspek penyajian, guru 1 memberikan skor 4,2 kategori "baik" sedangkan guru 2 memberikan skor 4,3 dengan kategori "sangat baik". Aspek bahasa dan gambar dari guru 1 dan guru 2 berturut-turut adalah 4 dan 4,6, mempunyai kategori "baik" dan "sangat baik". Aspek penyajian mempunyai skor 4,05 dan 4,5 dan berkategori "baik" dan "sangat baik". Pada aspek kegrafikaanguru 1 memberikan skor 4,5 dan guru 2 memberikan skor 4,3, dan keduanyamempunyai kategori "sangat baik".

Kesimpulan aspek kelayakan isi, bahasa dan gambar, penyajian dan kegrafikaan dari guru bahasa Indonesia 1 adalah sebesar 4,2 berkategori "baik" sedangkan dari guru bahasa Indonesia 2 adalah sebesar 4,5 dengan kategori "sangat baik". Apabila hasil keempat aspek dari dua guru dicari rata-rata skornya, maka hasilnya adalah sebagai berikut: 
4286 Pengembangan Bahan Ajar Membaca Sastra Berbasis Pendekatan Kontekstual pada Siswa SMP - Junifer Siregar

DOI: https://doi.org/10.31004/edukatif.v3i6.1441

Tabel 11. Rata-Rata Skor Hasil Validasi Produk dari Guru Bahasa Indonesia 1 dan 2

\begin{tabular}{cccc}
\hline No. & Aspek Penilaian & $\begin{array}{c}\text { Rata-Rata } \\
\text { Skor }\end{array}$ & Kategori \\
\hline 1 & Kelayakan isi & 4,3 & Sangat Baik \\
\hline 2 & Bahasa dan gambar & 4,3 & Sangat Baik \\
\hline 3 & Penyajian & 4,3 & Baik \\
\hline 4 & Kegrafikaan & 4,4 & Sangat Baik \\
\hline & Jumlah & $\mathbf{1 7 , 3}$ & \\
\hline & Rata-Rata Skor & $\mathbf{4 , 3}$ & Sangat Baik \\
\hline
\end{tabular}

Tabel 12. Rata-Rata Skor Hasil Respon Siswa

\begin{tabular}{cccc}
\hline No. & Aspek Penilaian & $\begin{array}{c}\text { Rata-Rata } \\
\text { Skor }\end{array}$ & Kategori \\
\hline 1 & Kelayakan isi & 3,98 & Baik \\
\hline 2 & Keterbacaan bahasa dan gambar & 3,7 & Baik \\
\hline 3 & Penyajian bahan ajar & 3,8 & Baik \\
\hline 4 & Tampilan bahan ajar & 3,7 & Baik \\
\hline & Jumlah & $\mathbf{1 5 , 1 8}$ & \\
\hline & Rata-Rata Skor & $\mathbf{3 , 8}$ & Baik \\
\hline
\end{tabular}

Berdasarkan tabel di atas, keseluruhan empat aspek mempunyai skor yang tidak beda jauh, yakni 3,98, 3,7, 3,8, dan 3,7. Keempat aspek tersebut mempunyai kategori "baik". Saran dan pendapat dari siswa antara lain: masih terdapat salah dalam penulisan, seperti huruf yang seharusnya kapital, tidak ditulis kapital, kualitas kertas yang terlalu tipis sehingga tinta tembus ke belakang, print out gambar kurang jelas, lebih banyak lagi soal evaluasi, kunci jawaban sebaiknyaada penjelasan, ukuran buku yang terlalu besar, bisa ditambahkan lagi gambar, pewarnaan pada kegiatan kurang menarik, kolom kegiatan terlalu besar, penyajianmateri masih sudah bagus namun agar lebih memperhatikan salah ketik dan huruf kapital, sampul bisa diberi gambar yang menarik, percetakannya kurang rapi. Apabila skor keempat aspek dari ahli materi, guru, dan siswa disajikandalam bentuk diagram, berikut diagramnya.

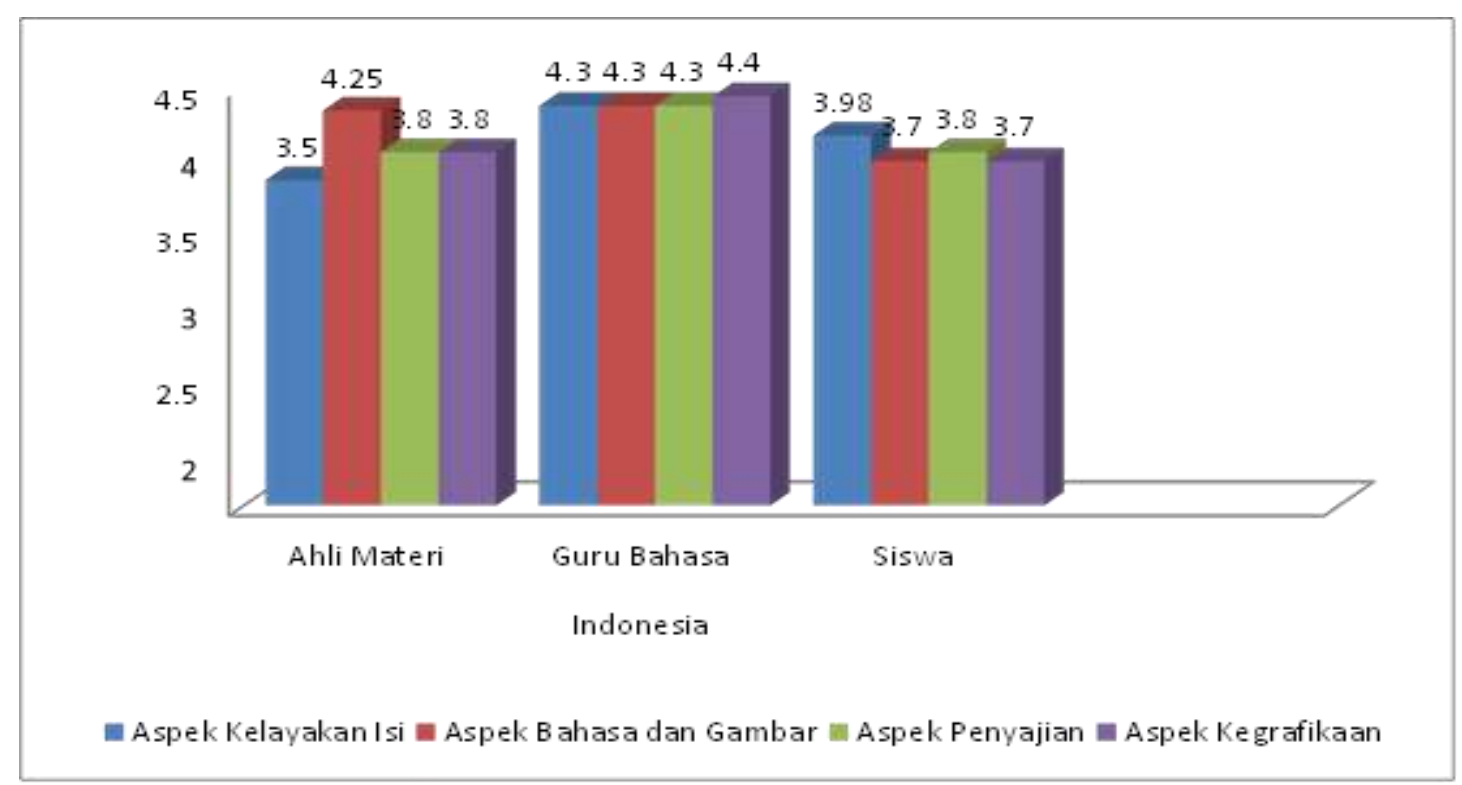

Gambar 1 Hasil Validasi 4 Aspek oleh Ahli Materi, Guru Bahasa Indonesia, dan Siswa 
Tujuan akhir penelitian ini adalah terciptanya produk yakni, "Bahan Ajar Membaca Sastra Berbasis Pendekatan Kontekstual pada Siswa Kelas VIII SMP”. Berdasarkan studi eksploratif yang digunakan untuk mengetahui wujud kontekstual yang terdapat pada RPP, buku pelajaran bahasa Indonesia yang digunakan, dan konteks kehidupan sehari-hari siswa, diperoleh beragam wujud kontekstual pada setiap strategi kontekstual. Adapun wujud kontekstual tersebut menjadi masukan dalam pembuatan bahan ajar membaca sastra. Berikut wujud kontekstual serta penerapannya pada buku ini.

Sesuai dengan karakteristik belajar kontekstual, pembelajaran harus berpusat pada siswa, buku ini memberikan umpan balik yang banyak dan segera sehingga siswa dapat mengetahui taraf hasil belajarnya. Guru hanya sebagai fasilitator, sebagai penyedia media maupun strategi. Penerapan pendekatan kontekstual pada setiap komponen buku diharapkan mampu menjadi salah satu referensi guru dalam kegiatan belajar mengajar. Di samping itu, diharapkan dapat meningkatkan membaca siswa. Pada penelitian ini, kelayakan buku yang dikembangkan ditentukan dengan nilai minimal "C", yaitu berkategori "cukup". Sesuai dengan pendapat (Hidayati \& Wiyarno, 2020), nilai "C" berada padarentang skor 2,6 $<X \leq 3,4$ dengan persentase 41 $60 \%$. Sementara itu, skor yang diperoleh berdasarkan penilaian ahli, guru, dan respon siswa pada penelitian ini adalah $X>3,4$ atau berkategori "baik" dengan nilai "B" dan $X>4,2$ atau berkategori "sangat baik" dengan nilai "A". Rata-rata skor yang diperoleh dari seluruh validator pada semua aspek adalah 3,97 atau berada dalam kategori "baik"dengan nilai "B" dan tingkat kelayakan 85,14\% Dengan demikian, bahan ajar membaca sastra berbasis kontekstual pada siswa kelas VIII SMP yang dikembangkan ini dianggap layak digunakan pada proses pembelajaran.

\section{KESIMPULAN}

Berdasarkan hasil penelitian dan pembahasan maka diperoleh kesimpulan sebagai berikut. Bahan ajar membaca sastra berbasis pendekatan kontekstual pada siswa kelas VIII SMP dikembangkan dengan tiga tahapan yaitu penelitian dan pengumpulan informasi, perencanaan pembuatan bahan ajar membaca sastra berbasis pendekatan kontekstual pada siswa kelas VIII, dan pengembangan bahan ajar membaca sastra berbasis pendekatan kontekstual pada siswa kelas VIII.

\section{DAFTAR PUSTAKA}

Aisyah, S., Noviyanti, E., \& Triyanto, T. (2020). Bahan Ajar Sebagai Bagian Dalam Kajian Problematika Pembelajaran Bahasa Indonesia. Jurnal Salaka: Jurnal Bahasa, Sastra, Dan Budaya Indonesia, 2(1).

Alpian, M. (N.D.). Kualitas Kegiatan Apresiasi Karya Sastra Siswa Smp Dalam Pembelajaran Bahasa Indonesia Di Lombok Timur. Proceeding Icete 2016, 436.

Ananda, R. (2019). Penerapan Metode Mind Mapping Untuk Meningkatkan Kemampuan Berpikir Kreatif Siswa Sekolah Dasar. Edukatif: Jurnal Ilmu Pendidikan, 1(1), 1-10.

Anas, M., \& Pdi, M. (2014). Mengenal Metodologi Pembelajaran. Muhammad Anas.

Atikah, D. (2017). Pengembangan Model Pembelajaran Berbasis Proyek Melalui Pendekatan Kontekstual Dalam Menulis Teks Berita. Semantik, 4(2), 123-152.

Duludu, U. A. T. A. (2017). Buku Ajar Kurikulum Bahan Dan Media Pembelajaran Pls. Deepublish.

Hamzah, R. (2019). Nilai-Nilai Kehidupan Dan Resepsi Masyarakat. Puspida.

Haryati, S. (2012). Research And Development (R\&D) Sebagai Salah Satu Model Penelitian Dalam Bidang Pendidikan. Majalah Ilmiah Dinamika, 37(1), 15.

Hasibuan, M. I. (2014). Model Pembelajaran Ctl (Contextual Teaching And Learning). Logaritma: Jurnal Ilmu-Ilmu Pendidikan Dan Sains, 2(01). 
4288 Pengembangan Bahan Ajar Membaca Sastra Berbasis Pendekatan Kontekstual pada Siswa SMP - Junifer Siregar

DOI: https://doi.org/10.31004/edukatif.v3i6.1441

Hidayati, A., \& Wiyarno, Y. (2020). Pengembangan Buku Ajar Ipa Kelas Vi Untuk Siswa Sekolah Dasar. Jems: Jurnal Edukasi Matematika Dan Sains, 8(2), 106-113.

Hutagaol, K. (2013). Pembelajaran Kontekstual Untuk Meningkatkan Kemampuan Representasi Matematis Siswa Sekolah Menengah Pertama. Infinity Journal, 2(1), 85-99.

Kurniawan, D. A., \& Astalini, A. (2019). Evaluasi Sikap Siswa Smp Terhadap Ipa Di Kabupaten Muaro Jambi. Jurnal Ilmiah Didaktika: Media Ilmiah Pendidikan Dan Pengajaran, 19(1), 124-139.

Panggabean, N. H., \& Danis, A. (2020). Desain Pengembangan Bahan Ajar Berbasis Sains. Yayasan Kita Menulis.

Pebriana, P. H. (2017). Peningkatan Keterampilan Menulis Puisi Bebas Dengan Menggunakan Pendekatan Kontekstual Siswa Sekolah Dasar. Publikasi Pendidikan, 7(2), 95-101.

Pohan, A. E. (2020). Konsep Pembelajaran Daring Berbasis Pendekatan Ilmiah. Penerbit Cv. Sarnu Untung.

Pramita, M., Mulyati, S., \& Susanto, H. (2016). Implementasi Desain Pembelajaran Pada Kurikulum 2013 Dengan Pendekatan Kontekstual. Jurnal Pendidikan: Teori, Penelitian, Dan Pengembangan, 1(3), 289296.

Rahmawati, I. Y. (2016). Cd Interaktif Sebagai Media Pembelajaran Berbahasa Bagi Anak Usia Dini Di Ponorogo. Jurnal Indria (Jurnal Ilmiah Pendidikan Prasekolah Dan Sekolah Awal), 1(1).

Sadjati, I. M. (2012). Pengembangan Bahan Ajar.

Siahaan, K. W. A., Haloho, U. N., Guk-Guk, M. P. A. R., \& Panjaitan, F. R. (2021). Implementation Of Discovery Learning Methods To Improve Science Skills In Kindergarten B Children. Jurnal Pendidikan Edutama, 8(1), 33-40.

Simanjuntak, M. P., Sinaga, L., Hardinata, A., \& Simatupang, H. (2020). Pengembangan Program Dalam Pembelajaran. Pt. Mediaguru Digital Indonesia.

Suryaman, M. (2008). Pengembangan Model Buku Pelajaran Bahasa Indonesia Berbasis Pembelajaran Kontekstual. Diksi, 15(1).

Suryaman, M. (2015). Analisis Hasil Belajar Peserta Didik Dalam Literasi Membaca Melalui Studi Internasional (Pirls) 2011. Litera, 14(1).

Susanti, D. (2019). Penerapan Pendekatan Pembelajaran Kontekstual Untuk Meningkatkan Minat Dan Keterampilan Menulis Pada Mata Pelajaran Bahasa Indonesia Di Kelas Iv Madrasah Ibtidaiyah Nurul Iman Kecamatan Kampa. Universitas Islam Negeri Sultan Syarif Kasim Riau.

Tantri, A. A. S. (2017). Hubungan Antara Kebiasaan Membaca Dan Penguasaan Kosakata Dengan Kemampuan Membaca Pemahaman. Acarya Pustaka: Jurnal Ilmiah Perpustakaan Dan Informasi, 2(1).

Wahyuni, T. (2020). Sintaksis Bahasa Indonesia Pendekatan Kontekstual. Penerbit Lakeisha. 